\title{
Physiology of Flower Development Stages in Siam Citrus Plants
}

\author{
Ni Putu Anom Sulistiawati, Ni. Komang Alit Astiari \\ \{anomsulistia@gmail.com\} \\ Agriculture Faculty of Warmadewa University, Denpasar
}

\begin{abstract}
.
There are some complexities in the physiological process of flowering in Siam orange till the formation of fruits. This is shown by the limited available information about maintaining an already induced flower till fruit formation periods. Threrefore, the aim of this study was to determine the flower development stages in a six-year-old Siam citrus plant flowers till the formation of fruit and to find out its flowering stages, as well as the endogenous role contained in these stages. The study was conducted in Catur Village, Kintamani Subdistrict, Bangli Regency in 2019. The research procedure involved the implementation of randomly selected 70 citrus plants from 36 different types, in the laboratory and on the field. The randomized block design method with one independent variable with 15 replications was used in this research. The identified results from the morphological identification showed the following physiological stages of flowering development: a) Before flower induction, b) Induction c) Flower bud development towards anthesis, d) Flower blooming, which is the stage when blooming or anthesis occurs. In addition, the statistical analysis results between the on-season and off-season periods showed no significant difference during the shoot development in the Siam citrus plants. However, it takes longer time for the shoot development in the off-season compared to the on-season, which was 204.03 days and 172.41 days, respectively.
\end{abstract}

Keywords: Flowering, Induction, Initiation, Differentiation, Blooming Flowers and $\mathrm{C} / \mathrm{N}$ ratio

\section{Pendahuluan}

Jeruk merupakan salah satu komoditas buah-buahan yang cukup penting didunia. Jeruk Siam (Nobilis var, microcarpa.L)) termasuk kedalam keluarga Anacardiaceae (Bally, 2006). Jeruk termasuk komoditas buah-buahan yang paling banyak diproduksi kedua di dunia setelah 
komoditas pisang dan mangga telah banyak dibudidayakan diberbagai dunia baik di daerah dengan iklim tropis maupun subtropis (Yahia, 2011).

Pada kegiatan produksi jeruk, tahap pembungaan pada tanaman jeruk Siam menjadi salah satu penentu dalam produksi buah, sehingga tahap pembungaan merupakan bagian penting dalam kegiatan produksi. Pembungaan merupakan tahapan pertama dalam kegiatan produksi buah jeruk di setiap tahun. Perkembangan tanaman khususnya pembungaan bergantung pada beberapa faktor lingkungan dan internal dari tanaman jeruk yang diusahakan. Daerah subtropis, faktor lingkungan yang mempengaruhi pembungaan adalah faktor suhu. Suhu $18{ }^{\circ} \mathrm{C}$ di siang hari dan $10^{\circ} \mathrm{C}$ di malam hari memicu perkembangan bunga di daerah subtropis. Untuk daerah tropis, faktor suhu tidak sangat mempengaruhi terhadap pembungaan karena perubahan suhu tiap musimnya tidak terlalu tegas. Cekaman kekeringan umumnya dapat memicu pembungaan di daerah tropis. Dalam pembungaan jeruk, terdapat adanya rangsangan yang disebut florigenic promoter (FP). Adapun pertumbuhan vegetatif dikendalikan oleh rangsangan induksi berupa vegetatif promoter (VP). Fitohormon pun memiliki peran dalam pembungaan jeruk. Fitohormon yang berperan dalam pembungaan antara lain auksin, sitokinin, etilen, dan giberelin. Adapun $\mathrm{C} / \mathrm{N}$ rasio yang meningkat menyebabkan terjadinya peningkatan karbohidrat yang tinggi dan mendukung inisiasi bunga. Adanya akumulasi karbohidrat pada bagian tajuk pada masa vegetatif akhir dapat memicu pembungaan. Tanaman jeruk Siam menginterprestasikan isyarat untuk pertumbuhannya sangat ditentukan oleh faktor lingkungan dan endogen serta tanaman buah tersebut (Ogaya, 2009). Dalam fenomena terbentuk pembungaan, fruit - set dan perkembangan buah sampai menjadi buah panen pada tanaman jeruk Siam merupakan fenomena yang sangat unit yang selama ini masih perlu pengkajian yang lebih mendalam. Transsisi pembungaan adalah faktor kunci yang menentukan produktivitas terbentuknya buah (Parvathi et al., 2014).

Fenomena pembungaan pada tanaman buah-buahan khususnya buah jeruk Siam merupakan suatu kejadian kompleks, yang secara morfologi terjadi perubahan dari fase vegetatif ke fase reproduktif (Sulistiawati dan Kartini, 2016), Saat dimulainya pembungaan terjadi peralihan dari struktur daun yang relatif sederhana menjadi struktur bunga yang lebih kompleks (Suaria et al., 2017). Hal tersebut diawali dengan berhentinya meristem membentuk calon daun dan mulai menghasilkan organ bunga (Nazeer et al., 2014). Jumlah bunga yang dihasilkan oleh tanaman ditentukan oleh pucuk per tanaman (Sulistiawati et al., 2017), karena sifat pembungaan dari beberapa tanaman buah-buahan sifatnya yang terminalis yaitu bunga tumbuh dan muncul hanya dari ujung-ujung pucuk. Selanjutnya intensitas polinasi dan fertilasi tidak mempengaruhi jumlah buah yang dapat dipanen. Jadi jumlah buah panen pada tanaman jeruk sangat ditentukan oleh jumlah pucuk berbunga dan kemampuan tanaman untuk mempertahankan agar bunga dan buah tidak gugur.

Berdasarkan latar belakang tersebut, penelitian ini bertujuan untuk mengetahui fase-fase perkembangan bunga pada tanaman jeruk sampai terbentuk calon buah atau fruit-set dan untuk mengetahui fase-fase pembungaan yang dialami tanaman jeruk Siam, serta peran endogen yang terkandung pada masing-masing fase pembungaan tanaman jeruk Siam.

\section{Metode Penelitian}

\subsection{Waktu dan Tempat Penelitian}


Penelitian dilakukan di Desa Catur, Kecamatan Kintamani, Kabupaten Bangli tahun 2019 dengan pengamatan di lapangan dan dilaboratorium dengan melakukan analisis jaringan.

\subsection{Bahan dan Alat}

Tanaman jeruk yang diteliti yang sudah berumur 6 tahun pemeliharaan rutin berupa, pemberantasan penyakit jamur pada kulit batang tanaman jeruk dengan memakai bahan penmbasmi penyakit Alika dengan dosis 1-2 ml/liter air dan untuk pencegahan hama biasanya digunakan Syngenta dengan dosis $0,2-0,4 \mathrm{ml} /$ liter air. Menggaruan dan pembersihan gulma, pemangkasan ranting yang menggagu.

\subsection{Prosedur penelitian}

Pelaksanaannya dilaksanakan di lapangan dan di laboratorium pada tanaman jeruk sebanyak 70 tanaman yang diambil secara acak dari 36 tanaman yang dipakai sebagai penelitian. a)Pengumpulan contoh dan pengamatan langsung aspek morfologi bunga gugur dan bunga tidak gugur. Bunga dikategorikan berhasil mengalami fruit-set apabila saat petalnya gugur, bunga tersebut masih tetap bertahan di pohon dengan kata lain tidak mengalami keguguran. Pengamatan dilakukan terhadap aspek perkembanga bunga sampai terbentuk calon buah. Pengamatan dilakukan setiap hari setelah tanaman sudah mengalami pemekaran bunga, sedangkan untuk sebelum induksi sampai terjadi induksi 3 hari sekali, pada pengamatan ini dilakukan pengukuran iklim mikro, seperti kelembaban, suhu udara. b) Penelitian di Laboratorium untuk pengamatan perubahan kandungan endogen pada pucuk yang berbunga gugur dan pucuk bunganya tetap di pohon.

\subsection{Rancangan Penelitian}

Penelitian menggunakan Rancangan Acak kelompok dengan satu faktor peubah tak bebas dengan 15 ulangan (dari 36 tanaman). Faktor sebagai peubah tidak bebas tersebut adalah periode pembungaan terdiri identifikasi kandungan endogen dan perkembangan bunga menjadi calon buah bertahan dan gugur menjadi calon buah pada tanaman jeruk siam serta peran lingkungan dalam pembungaan.

\subsection{Variabel yang Diamati.}

Pengamatan di lapangan yaitu pertumbuhan bunga jadi calon buah yang diamati: meliputi :

1. Pengamatan di lapangan yaitu: a). mengamati tanaman yang pucuknya berbunga sampai proses fase-fase terjadinya pembungaan di pohon, b). mengamati tanaman yang pucuknya berbunga sampai bisa terbentuk calon buah namun mengalami keguguran, pengamatan ini dilakukan setelah tanaman bebunga sampai terbentuk calon buah sebesar kelereng.

2. Pengamatan di laboratorium meliputi mengukur kandungan endogen yaitu kandung Gula gula total, gula reduksi, sukrosa, hara N, P, K dan nisbah C:N dianalisis adalah buah gugur serta bunga tidak gugur bunga jadi buah muda pada waktu yang sama pagi hari dan segera dimasukkan ke dalam termos berisi es.Setelah sampai di laboratorium dikeringkan dengan oven. Sesudah kering sampel disimpan dalam freezer dilakukan secara bersamaan setelah pengumpulan sampel selesai dlaksana.Kandungan hara $\mathrm{N}, \mathrm{P}$ dan $\mathrm{K}$ daun ( $\mathrm{N}$ total) dianalisis dengan metode Kjeldahl, $\mathrm{P}$ tersedia (metode Olsen dan Bray), K-total (metode $\mathrm{HCl} \mathrm{25 \% )} \mathrm{menurut}$ 
cara Yoshida et al (1992) dan pengamatan di lapangan iklim mikro meliputi suhu udara, kelembaban, dan curah hujan.

\section{Hasil dan Pembahasan}

\subsection{Periode Perkembangan pada Berbagai Stadia Pertumbuhan Vegetatif Tanaman Jeruk Siam.}

Pertumbuhan dan perkembangan tanaman jeruk Siam terdiri atas dua stadia, yaitu fase vegetatif (juvenile), dan fase reproduktif. Fase vegetatif terjadi setelah usai masa berbunga atau berbuah. Fase reproduktif terjadi pada periode pembentukan dan perkembangan kuncup bunga, bunga, dan buah. Transisi pertumbuhan vegetatif ke pertumbuhan reproduktif pada tanaman jeruk Siam sangat spesifik menghasilkan pertumbuhan dan perkembangan. Tanaman jeruk Siam dibedakan menjadi empat stadium pertunasan yaitu: (a) tunas awal, (b) tunas penuh, (c) tunas dewasa dan (d) tunas dormansi. Hasil pengamatan secara makroskopis pada morfologi yang dilakukan pada perubahan daun yang dialami oleh tanaman jeruk Siam selama satu periode perkembangan seperti pada Fig 3.1. Hasil analisis statistik antara periode onseason dan off-season menunjukkan perbedaan yang tidak nyata selama perkembangan pucuk pada tanaman jeruk Siam, namun demikian pada periode off-season dibutuhkan waktu yang lebih lama untuk perkembangan pucuk bila dibandingkan dengan on-season yaitu masingmasing: 204,03 hari dan 172,41 hari (Tabel 3.1).

Tabel 1. Rata-rata stadium pertumbuhan antara jenis pucuk pada periode on-season dan off-season pada tanaman jeruk Siam

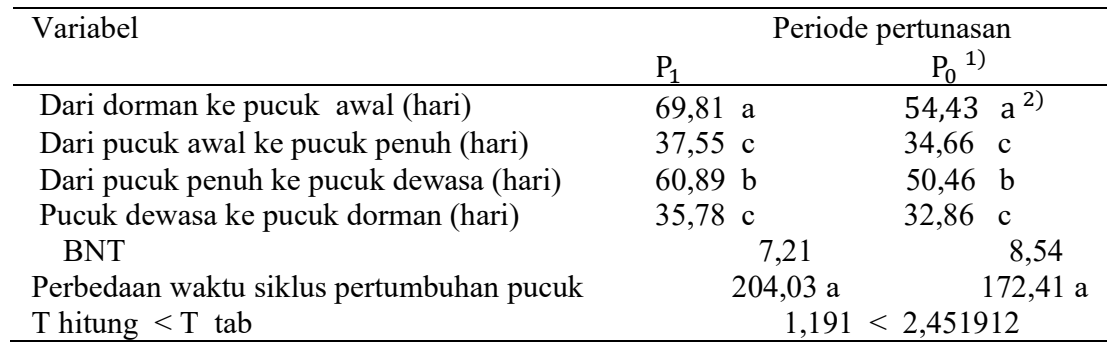

Keterangan:

1. Periode pertumbuhan pucuk pada tanaman jeruk Siam lama waktu yang dibutuhan lebih cepat pada periode on-season $\left(\mathrm{P}_{0}\right)$ bila dibandingkan pad periode off-season $\left(\mathrm{P}_{1}\right)$.

2. Angka-angka yang diikuti oleh huruf yang sama pada kolom yang sama menunjukkan pengaruh yang tidak nyata $p$ tidak nyata pada taraf 5\% dengan uji BNT 5\%.

Perkembangan Pertunasan Tanaman Jeruk Siam 

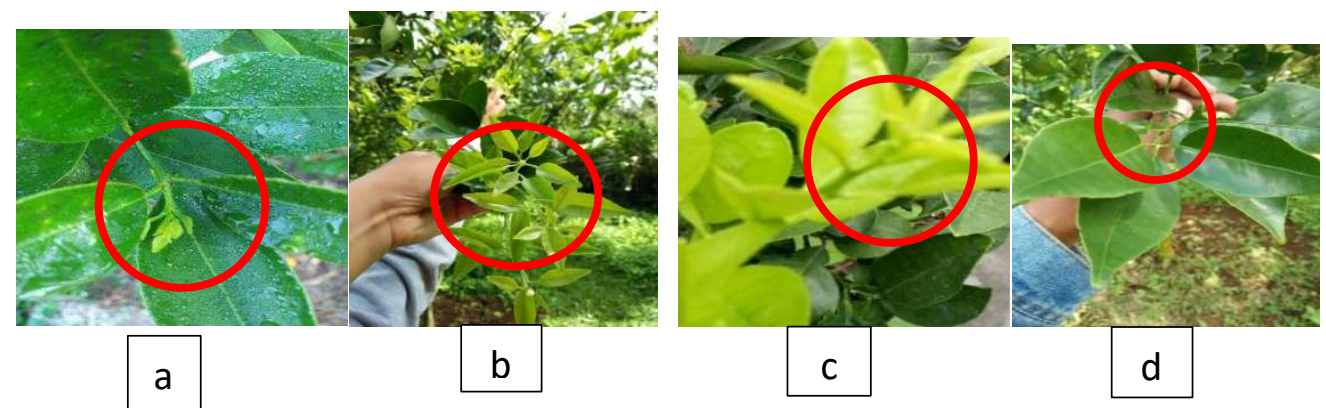

Fig 1 Foto pertumbuhan a)pucuk awal, b)pucuk penuh c)pucuk dewasa dan d)pucuk dorman diamati secara makroskopis pada tanaman jeruk Siam (Dokumentasi pribadi, 2017).

\subsection{Stadia Pembungaan Tanaman Jeruk Siam}

Hasil identifikasi perubahan secara morfologi fase-fase pembungaan secara makroskopis mulai dari sebelum induksi, induksi, inisiasi sampai bunga mekar/full bloom dan diskripsi singkat Fig foto yang menunjukkan kejadian-kejadian penting fase-fase perkembangan bunga jeruk Siam disajikan pada Fig 5.2. Fase-fase perkembangan pembungaan ialah: a) Sebelum induksi, b) Induksi bunga c) perkembangan kuncup bunga menuju anthesis, d) pemekaran bunga tahap ketika terjadi pemekaran bunga atau anthesis.

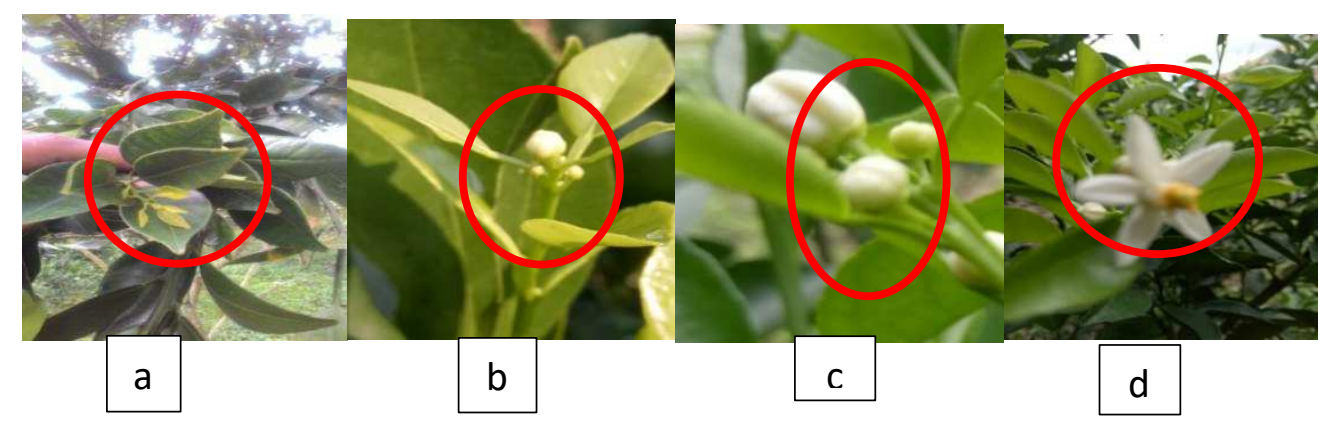

Fig 2. Karakter fase-fase perkembangan fisiologi pembungaan a) sebelum induksi, b) induksi, c) diferensiasi dan d) bunga mekar pada tanaman jeruk Siam.

Tabel. Interaksi antara jenis pucuk dan fase-fase perkembangan bunga terhadap kandungan gula total daun $(\%)$.

\begin{tabular}{|c|c|c|c|c|c|c|c|c|}
\hline \multirow{2}{*}{\multicolumn{3}{|c|}{$m$ Jenis pucuk $(\mathrm{B})^{1)}$}} & \multicolumn{6}{|c|}{ Fase-fase perkembangan bunga $(\mathrm{F})$} \\
\hline & & & \multirow[t]{2}{*}{$\mathrm{F}_{0}$} & \multicolumn{3}{|c|}{$\mathrm{F}_{1}$} & \multirow{2}{*}{$\frac{F_{2}}{34,07 a^{2)}}$} & \multirow[t]{2}{*}{$\mathrm{F}_{3}$} \\
\hline $\mathrm{B}_{0}$ & 17,58 & $\mathrm{a}$ & & 18,83 & $\mathrm{~b}$ & $24,54 \mathrm{~b}$ & & \\
\hline $\mathrm{B}_{1}$ & 13,41 & $\mathrm{a}$ & & 17,63 & $\mathrm{a}$ & $23,03 \mathrm{~b}$ & $23,03 \mathrm{~b}$ & \\
\hline & BNT & 1,76 & & & & & & \\
\hline
\end{tabular}

Keterangan :

1) $\mathrm{B}_{0}=$ Pucuk berbunga, $\mathrm{B}_{1}=$ Pucuk tidak berbunga, $\mathrm{F}_{0}=$ Sebelum induksi, $\mathrm{F}_{1}=$ Induksi, $\mathrm{F}_{2}=$ Diferensiasi, $\mathrm{F}_{3}=$ Bunga mekar.

2) Angka yang diikuti oleh huruf yang sama dalam 1 variabel yang sama menunjukkan pengaruh berbeda tidak nyata pada uji BNT 5\%. 
Tabel 3 Interaksi antara jenis pucuk dan fase-fase perkembangan bunga terhadap Kandungan gula reduksi daun $(\%)$

\begin{tabular}{cccccc}
\hline \multirow{2}{*}{ Jenis pucuk (B) ${ }^{1)}$} & \multicolumn{5}{c}{ Fase-fase perkembangan bunga (F) } \\
\cline { 3 - 7 } & & $\mathrm{F}_{0}$ & \multicolumn{1}{c}{$\mathrm{F}_{1}$} & $\mathrm{~F}_{2}$ & $\mathrm{~F}_{3}$ \\
\hline $\mathrm{B}_{0}$ & $12,88 \mathrm{a}$ & $14,33 \mathrm{~b}$ & $14,33 \mathrm{~b}$ & $16,04 \mathrm{a}^{2)}$ \\
$\mathrm{B}_{1}$ & $11,16 \mathrm{a}$ & $14,63 \mathrm{a}$ & $14,03 \mathrm{~b}$ & $13,00 \mathrm{~b}$ & \\
\hline \multicolumn{2}{c}{$\mathrm{BNT}$} & 1,60 & \multicolumn{5}{l}{} \\
\hline
\end{tabular}

Keterangan :

1). $\mathrm{B}_{0}=$ Pucuk berbunga, $\mathrm{B}_{1}=$ Pucuk tidak berbunga, $\mathrm{F}_{0}=$ Sebelum induksi, $\mathrm{F}_{1}=$ Induksi, $\mathrm{F}_{2}=$ Diferensiasi, $\mathrm{F}_{3}=$ Bunga mekar.

2). Angka yang diikuti oleh huruf yang sama dalam 1 variabel yang sama menunjukkan pengaruh berbeda tidak nyata pada uji BNT 5\%.

Tabel 4. Interaksi antara jenis pucuk dan fase-fase perkembangan bunga terhadap Kandungan Sukrosa daun $(\%)$

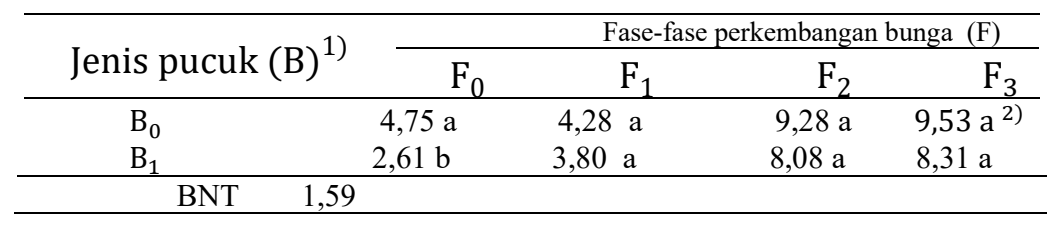

Keterangan :

1). $\mathrm{B}_{0}=$ Pucuk berbunga, $\mathrm{B}_{1}=$ Pucuk tidak berbunga, $\mathrm{F}_{0}=$ Sebelum induksi, $\mathrm{F}_{1}=$ Induksi, $\mathrm{F}_{2}=$ Diferensiasi, $\mathrm{F}_{3}=$ Bunga mekar.

2). Angka yang diikuti oleh huruf yang sama dalam 1 variabel yang sama menunjukkan pengaruh berbeda tidak nyata pada uji BNT 5\%.

Tabel 5 Interaksi antara jenis pucuk dan fase-fase perkembangan bunga terhadap Kandungan

Nutrisi N daun (\%)

\begin{tabular}{|c|c|c|c|c|}
\hline \multirow{2}{*}{ Jenis pucuk $(B)^{1)}$} & \multicolumn{4}{|c|}{ Fase-fase perkembangan bunga $(\mathrm{F})$} \\
\hline & $\mathrm{F}_{0}$ & $\mathrm{~F}_{1}$ & $\mathrm{~F}_{2}$ & $\mathrm{~F}_{3}$ \\
\hline $\mathrm{B}_{0}$ & 1,48 a & $1,41 \mathrm{a}$ & $1,30 \mathrm{a}$ & $1,16 a^{2)}$ \\
\hline $\mathrm{B}_{1}$ & $1,06 \quad \mathrm{a}$ & $1,26 \quad \mathrm{a}$ & $1,26 \quad \mathrm{a}$ & $1,15 \mathrm{a}$ \\
\hline BNT & & & & \\
\hline
\end{tabular}

Keterangan :

1). $\mathrm{B}_{0}=$ Pucuk berbunga, $\mathrm{B}_{1}=$ Pucuk tidak berbunga, $\mathrm{F}_{0}=$ Sebelum induksi, $\mathrm{F}_{1}=$ Induksi, $\mathrm{F}_{2}=$ Diferensiasi, $\mathrm{F}_{3}=$ Bunga mekar.

2). Angka yang diikuti oleh huruf yang sama dalam 1 variabel yang sama menunjukkan pengaruh berbeda tidak nyata pada uji BNT 5\%.

Tabel 6 Interaksi antara jenis pucuk dan fase-fase perkembangan bunga terhadap Kandungan Nutrisi P daun $(\%)$ 


\begin{tabular}{|c|c|c|c|c|c|c|c|}
\hline \multirow[t]{2}{*}{ Jenis pucuk $(\mathrm{B})^{1)}$} & \multicolumn{7}{|c|}{ Fase-fase perkembangan bunga $(\mathrm{F})$} \\
\hline & $\mathrm{F}_{0}$ & & $\mathrm{~F}_{1}$ & & $\mathrm{~F}_{2}$ & & $\mathrm{~F}_{3}$ \\
\hline $\mathrm{B}_{0}$ & 0,41 & a & 0,15 & $\mathrm{a}$ & 0,04 & $\mathrm{a}$ & $0,02 a^{2)}$ \\
\hline $\mathrm{B}_{1}$ & 0,03 & $\mathrm{~b}$ & 0,03 & $\mathrm{~b}$ & 0,02 & $\mathrm{a}$ & $0,02 \mathrm{a}$ \\
\hline
\end{tabular}

Keterangan :

1). $\mathrm{B}_{0}=$ Pucuk berbunga, $\mathrm{B}_{1}=$ Pucuk tidak berbunga, $\mathrm{F}_{0}=$ Sebelum induksi, $\mathrm{F}_{1}=$ Induksi, $\mathrm{F}_{2}=$ Diferensiasi, $\mathrm{F}_{3}=$ Bunga mekar.

2). Angka yang diikuti oleh huruf yang sama dalam 1 variabel yang sama menunjukkan pengaruh berbeda tidak nyata pada uji BNT 5\%.

Tabel 7 Interaksi antara jenis pucuk dan fase-fase perkembangan bunga terhadap Kandungan Nutrisi K daun (\%)

\begin{tabular}{ccccc}
\hline Jenis pucuk (B) $)^{1)}$ & \multicolumn{5}{c}{ Fase-fase perkembangan bunga $(\mathrm{F})$} \\
\cline { 2 - 5 } & $\mathrm{F}_{0}$ & $\mathrm{~F}_{1}$ & $\mathrm{~F}_{2}$ & $\mathrm{~F}_{3}$ \\
\hline $\mathrm{B}_{0}$ & $1,41 \mathrm{a}$ & $1,12 \mathrm{a}$ & $1,04 \mathrm{a}$ & $1,09 \mathrm{a}^{2}$ \\
$\mathrm{~B}_{1}$ & $1,04 \mathrm{~b}$ & $0,14 \mathrm{~b}$ & $0,01 \mathrm{~b}$ & $0,01 \mathrm{~b}$ \\
\hline BNT & 0,31 & \multicolumn{4}{c}{} \\
\hline
\end{tabular}

Keterangan :

1). $\mathrm{B}_{0}=$ Pucuk berbunga, $\mathrm{B}_{1}=$ Pucuk tidak berbunga, $\mathrm{F}_{0}=$ Sebelum induksi, $\mathrm{F}_{1}=$ Induksi, $\mathrm{F}_{2}=$ Diferensiasi, $\mathrm{F}_{3}=$ Bunga mekar.

2). Angka yang diikuti oleh huruf yang sama dalam 1 variabel yang sama menunjukkan pengaruh berbeda tidak nyata pada uji BNT 5\%.

Tabel 8 Interaksi antara jenis pucuk dan fase-fase perkembangan bunga terhadap Kandungan Ratio $\mathrm{C} / \mathrm{N}$ daun $(\%)$

\begin{tabular}{crrrcc}
\hline Jenis pucuk (B) & \multicolumn{5}{c}{ Fase-fase perkembangan bunga $(\mathrm{F})$} \\
\cline { 2 - 6 } & $\mathrm{F}_{0}$ & \multicolumn{5}{c}{$\mathrm{F}_{1}$} & $\mathrm{~F}_{2}$ & $\mathrm{~F}_{3}$ \\
\hline $\mathrm{B}_{0}$ & & $15,61 \mathrm{a}$ & $41,83 \mathrm{a}$ & $18,54 \mathrm{a}$ & $23,59 \mathrm{~b}^{2)}$ \\
$\mathrm{B}_{1}$ & & $10,30 \mathrm{a}$ & $13,63 \mathrm{a}$ & $22,15 \mathrm{a}$ & $22,80 \mathrm{ab}$ \\
\hline $\mathrm{BNT}$ & 1,59 & \multicolumn{3}{c}{} \\
\hline
\end{tabular}

Keterangan :

1). $\mathrm{B}_{0}=$ Pucuk berbunga, $\mathrm{B}_{1}=$ Pucuk tidak berbunga, $\mathrm{F}_{0}=$ Sebelum induksi, $\mathrm{F}_{1}=$ Induksi, $\mathrm{F}_{2}=$ Diferensiasi, $\mathrm{F}_{3}=$ Bunga mekar.

2). Angka yang diikuti oleh huruf yang sama dalam 1 variabel yang sama menunjukkan pengaruh berbeda tidak nyata pada uji BNT 5\%.

\subsection{Fenofisiologi Pembungaan pada Tanaman Jeruk Siam}

Fenofisiologi pertumbuhan dan perkembangan tanaman jeruk Siam terdiri atas dua stadia, yaitu fase vegetatif (juvenile), dan fase reproduktif. Fase vegetatif terjadi setelah usai masa berbunga atau berbuah. Fase reproduktif terjadi pada periode pembentukan dan perkembangan kuncup bunga, bunga, dan buah. Proses fase vegetatif mulai dari 1) pucuk awal, dengan ciriciri terjadinya perubahan dari daun berwarna hijau tua menjadi titik tumbuh ke pertumbuhan perkembangan pucuk awal, ini terjadi mulai dari hari ke 0 sampai hari ke 54,43 hari. Pada pertumbuan dan perkembangan pucuk awal masih terjadi pertambahan daun yang berkembang. 2) pucuk penuh, dengan ciiri-ciri mulai terjadi perkembangan daun menjadi daun 
yang lebih dewasa membutuhkan waktu selama 34,66 hari sampai menjadi pucuk dewasa dengan tanda masih terjadi pertambahan jumlah daun yang tumbuh. 3) pucuk dewasa waktu yang dibutuhkan yaitu selama 50,46 hari dengan tanda tidak terjadi pertambahan jumlah daun yang tumbuh, dan 4) pucuk dorman derngan tanda pertambahan daun berhenti lebih cepat dan daun akan bertambah tua bersamaan dengan pertumbuhan dewasa sampai pertumbuhan pucuk dorman (Fig 4.3).

\subsection{Perkembangan Bunga dan Buah Jeruk Siam.}

Proses pembungaan yang dimulai saat ketiak/pucuk daun dorman untuk terinduksi menjadi bunga, seringkali tidak terjadi pada keseluruhan ketiak/pucuk tanaman buah-buahan. Proses pembungaan mengandung sejumlah tahap penting, yang semuanya harus berhasil dilangsungkan untuk memperoleh buah. Masing-masing tahap tersebut yaitu: sebelum induksi tahap pertama dari proses pembungaan, yaitu suatu tahap ketika meristem vegetatif mulai berubah menjadi meristem reproduktif, terjadi di dalam sel, dapat dideteksi secara kimia dari peningkatan sintesis asam nukleat dan protein yang dibutuhkan dalam pembelahan dan perkembangan sel, waktu yang dibutuhkan 69,23 hari. Induksi bunga tahap ketika perubahan morfologis menjadi bentuk kuncup reproduktif mulai dapat terdeteksi secara makroskopis untuk pertama kalinya, waktu yang dibutuhkan 34,75 hari.

Pengamatan terhadap perkembangan bunga jeruk Siam secara morfologi dimulai dari tunas mnculnya kuncup bunga (tahap I) dan pembesaran kuncup bunga ke ukuran maksimal atau difrensiasi (tahap II), bunga mulai membuka sampai saat anthesis, perkembangan kuncup bunga menuju anthesis biasanya disebut diferensiasi yaitu bagian-bagian bunga pada fase ini terjadi proses megasporogenesis dan mikroporogenesis untuk penyempurnaan dan pematangan organ-organ reproduksi jantan dan betina (tahap III), selanjutnya bunga mulai mengalami kerontokan perhiasan bunga (tahap IV), dan selanjutnya terbentuk fruit-set (tahap V), Pada tahap I terjadi perubahan baik perubahan bentuk maupun organ reproduktif yang ditandai dengan munculnya dan pembesaran kuncup bunga ke ukuran maksimal. Pengamatan dilakukan pada saat kuncup bunga berukuran $0,1 \mathrm{~cm}$ hngga kuncup bunga mulai membuka, untuk tanaman jeruk Siam berlangsung 8-10 hari dengan ukuran kuncup bunga maksimal 0,6$0,7 \mathrm{~cm}$. Pada tahap II merupakan periode mulai membukanya kuncup bunga sampai dengan mekarnya bunga atau anthesis. Pada fase ini bunga jeruk sudah kelihatan benang sarimya berwarna kuning, degan mahkota bunga berwarna putih dengan dasar berwarna hijau. Lama waktu berlangungnya periode tahap ini yaitu 6-7 hari. Pada tahap III ditandai dengan bunga mulai mekar sempurna, berlangsung 2-3 hari hingga bagian-bagian perhiasan bunga mulai mengalami kerontokan. Tahap IV dan tahap V bunga rontok hingga terbentuk fruit-set. Tahap perkembangan bunga jeruk Siam disajikan pada Fig 4.4.

Pembungaan jeruk Siam sebagai peristiwa reproduksi merupakan kunci utama pada produksi buah. Tahapan setelah stadium anthesis atau bunga mekar maka proses pembungaan terlampaui, dan berikutnya terjadi penyerbukan atau polinasi selanjutnya terjadi pembuahan atau fertilization, pada saat ini terjadi bersaunya sel kelamin jantan dan betina. Pada pembuahan imti dari sperma serbuk sari dan inti sel telur melebur menjadi satu, selanjutnya mengalami perkembangan menjadi fruit-set, selanjutnya, buah muda, dan terakhir terbentuknya buah masak fisiologis aau buah siap panen (Fig 4.6).

Nisbah $\mathrm{C} / \mathrm{N}$ ratio mempunyai keterkaitan dengan induksi pembungaan, kalau kandungan karbohidrat dan nitrogen atau nisbah $\mathrm{C} / \mathrm{N}$ ratio pada tanaman atau jika $\mathrm{C} / \mathrm{N}$ ratio tinggi maka tanaman dapat menginduksi bunga, dan bila nisbah $\mathrm{C} / \mathrm{N}$ ratio rendah pada tanaman maka dipacu kearah pertumbuhan vegetatif. Pada prinsipnya terdapat tiga konsep pokok tentang induksi pembungaan yaitu: (1) adanya hormon pembungaan (florigen) atau stimulus 
pembungaan pada daun yang mengalihkan pertumbuhan vegetatif ke pertumbuhan reproduktif, (2) adanya kondisi nutrisi yang optimum bersamaan dengan perubahan dalam apex, dan (3) terjadi perubahan pada apex yang mengubah dan mengkonversi nutrien sehingga terjadi induksi pembungaan (Rai et al., 2010). Sejalan dengan hal tersebut, proses pembungaan mengandung sejumlah tahap penting, yang semuanya harus berhasil dilangsungkan untuk memperoleh buah. Masing-masing tahap tersebut depengaruhi oleh salah satunya adalah faktor endogen tanaman (Hovarth, 2009).

\section{Kesimpulan}

Berdasarkan hasil penelitian maka dapat disimpulkan hal-hal sebagai berikut:

1. Induksi dan perkembangan pembungaan tanaman jeruk Siam sangat dipengaruhi oleh lingkungan terutama cekaman kekeringan dan suhu udara. Pada periode off-season suhu udara lebih tinggi dengan kelembaban yang lebih rendah, menginduksi pertumbuhan vegetatif. Untuk mendapatkan buah off-season atau buah di luar musim dibutuhkan pengairan yang teratur yaitu bisa melalui penyiraman.

2. Pucuk terinduksi berbunga berhubungan dengan periode pembungaan, dimana kandungan nutrisi $\mathrm{N}, \mathrm{P}, \mathrm{K}$ dan $\mathrm{C} / \mathrm{N}$ ratio daun $1,12 \%, 0,37 \%, 1,50 \%$ dan $29,90 \%$ lebih tinggi pada periode on-season bila dibandingkan dengan periode off-season yaitu 1,04\%, 0,27\%, $0,54 \%$ dan $23,41 \%$.

\section{References}

[1] Nazeer Ahmad, Dinesh Kumar, Javid Iqbal Mir and A.A Pal (2014). Physiology of Flowering in Perennial Temperate Fruit Crops.The Society for Development of Subtropical Horticuture (SDSH) Rehmankhera, Lucknow 226-101, Uttar Pradesh. National Seminar cum-Workshop $24-$ 26 May 2014.

[2] Ogaya, R., J. Penuelas. 2007. Drought Effects on flower and fruit Production in a Mediterranean Oak Forest. An Ynternational Journal of Forest Research 80(3):351-357.

[3] Parvathi. M Sreekumar, Mahesh Salimath, Ramu. S.V and M. Udayakumar (2014). Current Status of Flowering control: Will it Propide Options for Chemical Regulation of Flowering? The Society for Development of Subtropical Horticuture (SDSH) Rehmankhera, Lucknow - 226-101, Uttar Pradesh. National Seminar cum-Workshop 24 - 26 May 2014.

[4] Suaria, I. N, Sulistiawati, N. P. A and Astiari, N. K. A. (2017). The Period of Leaf Level and the Conflict in Efforts to Get the Ordinary Siam Plant. International Research Journal of Engineering, IT \& Scientific Research (IRJEIS) Available online at http://ijcu.us/online/journal/index.php/irjeis Vol. 3 Issue 6, November 2017, pages: 21 31 ISSN: 2454-2261 Impact Factor: 5.211 | Thomson Reuters: K-4290-2016 http://dx.doi.org/10.21744/irjeis.v3i6.559.

[5] Sulistiawati N.P,A and Kartini. L. (1916). Identiifikasi fase-fase perkembangan dan perubahan pucuk berbunga dan tidak berbunga pada tanaman jeruk siam. Hibah fundamental yang dibiayai RISTIK DIKTI tahun anggaran 2016.

[6] Sulistiawati, N.P.A, Rai,I. N Santosa I.G.N and Astarini, I. A (2017) Flowering Position on Main Stem and Branches Affect FRUIT-SET in citrus Plant (Citrus nobilis var microcarpa L). International Research Journal of Engineering, IT \& Scientific Research (IRJEIS) Available online at http ://ijcu .us/online/journal/ index .php/irjeis Vol. 3 Issue 3, May 2017, pages: 71 78 ISSN: 2454-2261 Impact $\quad$ Factor:5.211ThomsonReuters:K42902016:http://dx.doi.org/1021744irjeis.v3i3.469

[7] Rai, I N., Semarajaya, C.G.A. dan Wiraatmaja, I.W. 2010. Studi Fenofisiologi Salak Gula Pasir Sebagai Upaya Mengatasi Kegagalan Fruit-set dan Memproduksi Luar Musim.J..Hort. 
[8] Yoshida S. Forno DA, Cock JH, Gomes. KA. 1972. Laboratory Manual for

[9] Physiological Studis of Rice Second Editon Los Banos. The International Rice Research Institute, Laguna Phippines. $70 \mathrm{hlm}$.

[10] Bally I.S.E., 2006, Mangifera indica (mango), Ver. 3.I, Dalam Elevitch, C. R., ed. Species Profiles for Pacific Island Agroforestry, Permanent Agriculture Resources (PAR), Holualoa, Hawaii 